\title{
Effect of Accounting Goals and Methods of Measurement Accounting Firms after Privatization of Jordan on the Financial Statements
}

\author{
Atallah Ahmad Hosban ${ }^{1}$ \\ ${ }^{1}$ Irbid National University, Irbid, Jordan \\ Correspondence: Atallah Ahmad Hosban, Almafraq, Jordan. Tel: 962-775-437-120. E-mail: \\ aalhosban@gmail.com
}

Received: June 11, 2014

Accepted: December 16, 2014

Online Published: January 25, 2015

doi:10.5539/ibr.v8n2p220

URL: http://dx.doi.org/10.5539/ibr.v8n2p220

\begin{abstract}
The study aimed to highlight the objectives of the privatization process of accounting and the extent of the application of Jordanian firms after privatization of those goals and also aimed to identify the application of the accounting methods of measuring the financial statements of companies. Study questionnaire was also used as a key tool to get the information, was the use of the arithmetic mean and standard deviation as methods of statistical. Study find the following results: The Jordanian firms after privatization disclose all financial statements in the financial statements process is applied and this means that it applies the principles of financial accounting accepted , and the information that explains the economic situation, and the project's financial feasibility and economic problems disclosed in financial statements. Most recommendation: changes in accounting and financial systems, and the quality of the available financial information, required after privatization, making divestitures decision such as the type of privatization method to use and its timing
\end{abstract}

Keywords: privatization, financial statements, accounting measurement, companies after privatization

\section{Introduction}

Privatization concept: Of the most important modern concepts where this term appeared for the first time privatization 1) the concept of privatization: The concept of privatization in 1983, but it quickly spread and was circulating in the economic literature. Privatization means: ownership of all or part of the transfer process Public sector institutions that produce goods or provide services to the private sector, and transform them into companies managed on a commercial basis, or: Is the sale of state-owned shares in some public shareholding companies partly or wholly to the private sector, namely: re- balance among Various economic sectors, and direction toward private property. Privatization is the strategy or the process which transfers totally or partially, an asset or enterprise which is owned or controlled, either directly or indirectly, by the state to private organizations. Also, privatization is a process of "empowerment" that makes people economic and political participants by creating opportunities for ownership (Ogden \& Anderson, 1999).

\subsection{Introduce the Problem}

Privatization in Jordan was not a mere economic luxury, a fad, or simulation of other countries' experiences, it was dictated and imposed on the Kingdom as a result of various surveys and studies of public-sector projects. The conclusions of said studies demonstrated the prevalence in the public sector institutions and corporations of a large degree of inefficiency in the administrative and employment policies, squander of public funds, administrative archaism, substandard services and high indebtedness, while the private sector firms were yielding higher returns and results and generating better job opportunities, given the high level of efficiency in the administrative and employment policies. So that Jordan is going through now is an important stage in the trend towards the privatization of public institutions and projects. It can be considered in $1985 \mathrm{AD}$ is Start thinking about privatization, when he was directing the Royal Government to book 4, which urged them to encourage the private sector to take Role in economic development, in line with global trends towards globalization of world trade liberalization of tariff barriers, and the need to Jordan 's openness to the world, through a partnership agreements with the European Union, and accession to the World Trade Organization, or orientation Establishment of an Arab free trade zone. 


\subsection{Explore Importance of the Problem}

Since an important objective of privatization is to remove the nationalized industries from political control in the belief that control by the market would ensure greater efficiency, structural differences to political motives behind privatization; grouping countries as developed, developing and former communist, although conceptually and methodologically useful, may obscure significant differences within each category. This research highlights the importance of the privatization policy in Jordan has become a continuous approach, studies have shown Conducted on public sector institutions in Jordan that there was a lot of chaos and humor of public money, and poor services provided by, and high indebtedness, while private sector companies achieve better results, and there are more job opportunities.

\subsection{Problem Study}

This study tries to answer the following questions:

1) Is the privatization company in Jordan benefit from the actual accounting objectives after privatization?

2) Is the privatization in company used the accounting method for privatization?

\subsection{Objectives Study}

This study aims to identify the goals and methods of accounting and accounting methods relating to the privatization process so that this study target for following:

1-To identify the targets of the accounting process of privatization and make sure of the extent of the application of those goals;

2- Identify the applicable accounting policies in companies after privatization;

3-Come up with results and recommendations will help researchers identify the companies actually applied in Jordan after privatization.

\subsection{Participant (Subject) Characteristics}

Difference in this study from previous studies:

1-This study focuses on the accounting objectives of the privatization process and the extent of Jordanian companies have benefited from those goals after privatization.

2-This study focuses on the accounting methods used to measure the financial statements of the terms and the extent of the use of these methods and how to disclose the methods of measurement in the financial statements.

\subsection{Research Design}

The research design consists of three main parts of the study is provided that has the problem and the importance of goals and methodology of the study and previous studies, and the second part is the theoretical framework that covers the variables and the problems of the study, and the third part is the statistical analysis and the results and recommendations of the study

\subsection{Experimental Manipulations or Interventions}

Four types of government policies can bring about a shift from the public to the private sector: (Gupta, 2000).

a) The cessation of public programs and the disengagement of government from certain responsibilities,

b) A transfer of public ownership and assets to private organizations,

c) The financing of private services through contracts or vouchers, and

d) Allowing the private sector to enter into those areas hitherto reserved exclusively for the public sector. Privatization programs are complex and all the key aspects (social, economic, political, etc) should be taken into account in the design of the program and components. The critical success factors for privatization programs may be as follows (Young P., 1998) establish a proper balance among objectives.

b) Thorough planning and education are vital.

c) Decision makers must be better educated so they can fully understand the need for privatization and the necessity of creating a solid institutional framework that will allow privatization to flourish.

\subsection{State Hypotheses and Their Correspondence to Research Design}

1 - there is no trace of the objectives of privatization accounting on the financial statement"

2- Do not use the companies after privatization accounting measurement methods in the preparation of financial 
statements

\section{Literature Review}

\subsection{Describe Relevant Scholarship}

1-Kerry Jacobs, 2009: Beyond commercial in confidence: accounting for power privatization in Victoria.

The purpose of this paper is to examine whether the use of commercial-in-confidence arrangements within the public sector allows the deliberate manipulation of accounting figures to generate support for the privatization agenda. Design/methodology/approach - A case study is presented of an Australian power entity, United Energy, where the privatization was subject to commercial-in-confidence restrictions and differing opinions as to the accuracy of the entity's financial accounts during the privatization process. It examines many of the key "commercial-in-confidence" documents, which are now available through parliamentary and official document sources, together with pre- and post-privatization financial statements. Findings - The accounting figures were shaped to support a privatization agenda and this was obscured by the commercial-in-confidence provision. Some attempts were made to use accounting arrangements to reduce federal taxes but this failed. A substantial element of the reported sale price represented internal transfers between the state-owned entity and the government with the actual price paid by the purchaser being substantially lower than the reported price. The price paid was based on the financial statements which were openly challenged by the Auditor-General. The paper strongly supports the contention that manipulation of accounting figures occurs under commercial-in-confidence privatizations.

\section{2- Andrea Mennicken, 2013: Accounting and Privatization in the Prison Service of England and Wales.}

the prison into a performance-oriented accounting entity. It examines the implication of private sector accounting and consulting expertise in redefining prison values and prison performance, and it discusses the consequences this had for definitions of risk and responsibility. The paper shows how the reforms promoted a systemic of Prison Service accountability. Prison managers and regulators came to be inserted into hierarchies of expertise and credibility shaped by quests for commensuration and audit ability. Further, the paper shows how the reform attempts brought about a situation of institutional lock-in by contributing, as the outgoing HM Chief Inspector of Prisons Anne Owers has put it in 2010, to the creation of an inflated prison system 'too big to fail, and too big to succeed .

\section{3- Yakup Selvi, 2010: The Importance of Financial Reporting During Privatization.}

Privatization has been on a lot of countries' agenda, especially for the emerging countries for a long time. In Turkey, as an emerging country, privatization plan has been a very high priority among the State Budget income items for three decades. To identify and to explore the accounting role in privatization is the critical issue for the countries under privatization process. In this study, the importance of financial reporting during privatization process is examined. The overall responsibility of accounting in privatization is to develop investor confidence to channel the flows of funds and to ensure the effective and efficient use of capital funds. Therefore, without a sound accountancy framework, the privatization process would not generate the desired long term economic, social, and financial development results. Therefore, we analyzed the period of Turkish privatization experience by underlying the importance of financial reporting in this process. For this purpose, in the first part of the study, we defined the privatization and argued the positive and negative opinions about it. In the second part, we clarified the role of accounting in privatization process under disclosure, transitional problems, training, valuation problems, and inflation accounting subsections. In the third part, we discussed the recent accounting developments which may effects privatization in Turkey. In the fourth part, we summarized the implementation of privatization in Turkey. Then, we mentioned the key issues in privatization process for emerging economies. Based on the Turkey's privatization practices, financial reporting has a very important role in the SOE's privatization process. In our point of view, since accounting has an important role in privatization, this role takes place before, during and also after the privatization. It should be taken into consideration that the main objective of privatization is not only to privatize SOE's, but also keep the sustainability of privatized SOE's. While privatization creates sources for new investments of the governments, it should support the effectiveness and economics of goods and services in the area of privatization. So the sustainability of privatized companies is very important as well as their sales. All of the above purposes can be controlled by solely accounting.

4-Shehan, 2008: Problematic privatization and its implications in raising the efficiency of economic performance.

The subject of privatization has been the focus of interest of researchers and those who have great interest in economic matters where it caused a lot of debate and controversy in these matters. From the scientific viewpoint, 
the subject of privatization cannot be discussed accurately without mentioning and discussing the Market Economy System and the role of the private sector in this system. It is known that privatization does not represent a gateway or an economic theory standing as a whole, but it is a tool or a means used by the existing economic policies in the country for the purpose of changing the economy from the central system based on the government control over all the economic activities into the market system based on the forces of supply and demand. The philosophy of the Market system is based on a set of assumptions like the private ownership of the means of the production, and the freedom of the individuals' movement and capitals. The conscious and objective perception to adopt or not adopt privatization in developing countries depends on the basis that the lesson lies in the possibility of the economic system based on public and private sectors in achieving higher levels of the efficiency of performance and the efficiency resource allocation. The area of both sectors in the economic activity depends on the view just mentioned. The principle of the acceptance and rejection of privatization under the political, social and economic conditions and traditions of the developing countries must be based on strong background to know which sector has the capacity to achieve the economic and social development .

\subsection{Accounting Objectives from Privatization (Craig \& Amernic, 2006)}

1- For making divestitures decision such as the type of privatization method to use and its timing

2- For fulfilling the investors needs, which usually include as a minimum the preparation of prospectus or information memorandum and business plan

3- For assessing how the public interest has been served in the government discharged of its stewardship function, including how will the privatization objectives has been met

4- Increase disclosure in financial statement after privatization

5- Attaining low cost specially operating cost

6- Making value added for financial statement after privatization by provide internal auditing and external auditing

7- Identification of property unsuitable for business activity as uncollectible claims, fixed and intangible assets , and investments items

8- Accounting language is important in telling the tale of privatization. Of particular importance are the specific constructs in that language - the accounting measures used to help construct the tale, give it a coursing thread through time, and generate rhetorical appeal

\subsection{Accounting Methods for Privatization (Mohmoud Aljabali, 2012)}

Concept valuation: valuation means the concept of determining the value of something, this value is measured replace strongly object to be privatized for other things, because they can not measure the value of things relative to each other money has been used to measure the value. The concept for the evaluation

1- To evaluate the assets of institutions, is to try to reach a financial value, but this value is indicative estimated.

2- Problems change in accounting systems: a change in accounting methods resulting from the transfer of ownership of accounting units

And changes in accounting and financial systems, and the quality of the available financial information, required after privatization.

3- Disclosure of information: the information that explains the economic situation, and the project's financial feasibility and economic problems For investors, with a statement of the date of his comparatively to previous years, with the expectations of the future, showing the extent of expected accomplishments, and benefits Expected, and usually auditor issued a special report for a specific order to protect the interests of prospective investors

4- Method based on assets: assets are evaluating depending on the estimated price of the sale between the seller and the buyer without pressure or coercion, and takes into account the way this first -current assets, which is not the subject of our research. Second, fixed assets, and we find: Tangible fixed assets, such as land, and must be evaluated according to the market price, taking into account the disposition of rights, The ownership or lease long-term rights, buildings, equipment and other productive assets, evaluate and also according to the market price or value Substitution after consumption

5- Existing method based on the replacement cost: represents the present value of the replacement owned enterprise assets have another The same energy with depreciation and any defects in the existing " a replacement 
cost in the event of sudden exposure to loss or damage

6- Rating based on the market value: The value is estimated based on the expected price of the shares in an efficient and active market for Using a multiplier market value consideration for the shares for profit or for the carrying value or fair comparison with the market value Where similar projects in terms of activity and size. In assessing the institutions are the basics analysis of the activity of the institution as it is the adoption of principles Specific estimate of intangible assets in terms of knowledge, professional and technical, brand, and spatial in commercial markets

Economists have argued that network utilities such as power represent a natural monopoly where the costs of infrastructure offer a virtually insurmountable barrier to competition. One solution to this monopoly problem was the state ownership and control of these assets. However, it was argued that as part of the process of privatization, these assets could be restructured with generation, distribution networks and the supply or sale of electricity being transformed into separate and stand-alone entities and regulation being installed to ensure effective competitive behavior in the newly created "power markets". Argue that privatization involved the following six (Craig \& Amernic, 2006).

- Obliging electric enterprises to operate according to commercial principles.

- Introduction of competition in order to improve sector performance.

- Restructuring or unbundling the electric supply chain to enable the introduction of competition. Breaking up the incumbent power utility into multiple generators and distributors of power that trade with each other in a competitive wholesale power market.

- Privatization of the unbundled electricity generators and distributors under dispersed ownership.

- Development of economic regulation of the power market.

- Focusing the government's role on policy formation and executing and divesting their role as operator and investor.

The growth of accounting within these public sector organizations can be seen as a response to this growing commercial and competitive environment also argued that the introduction of accrual accounting in the public sector was the first stage of the privatization process as the information that was needed to initiate privatization (the value of assets, liabilities and profitability) could be most efficiently collected under an accrual accounting regime (Kerry Jacobs, 2009).

Attempts aimed at reconstructing the prison as a private sector-oriented accounting entity have paved the way for these developments. They led to a shift in emphasis from the Prison Service as a whole to individual prison establishments. Notions of failure and failing have come to be connected to individual, failing prison organizations. Poor performance has come to be regarded as the failure of individual operational management which, in turn, has reinforced a focus on issues of 'structures' and 'systems' at the expense of softer, more subtle 'processes' and 'commitment (Coelye, 2007).

Government accounting is a key component of accountability and transparency by keeping the records of and reports the financial policy related government transactions. An advanced accounting and reporting system is the most reliable source of reference with respect to the current and future effects of the financial policies employed by the governments. Featuring this characteristic, government accounting provides timely, accurate and consistent information to all decision-makers as well as to decision-makers who are involved in privatization process. The overall responsibility of accounting in privatization is to develop investor confidence to channel the flows of funds and to ensure the effective and efficient use of capital funds. Therefore, without a sound accountancy framework (transparency and accountability), the privatization process would not generate the desired long term economic, social and financial development results, while furthermore enhancing the motivational attitudes in respective. Also, weak capital markets and poor enforcement of accounting regulations, a culture of tax avoidance, and accounting education inappropriate to the local environment caused a lack of transparency and accountability (Uddin \& Hopper, 2003).

Also, it will be difficult to proceed with effective privatization efforts if the financial management issues are not properly addressed, including in many countries the concepts and methods of valuation of properties, issuance of privatization procedures vouchers, presentation of financial statements, disclosure requirements, measurement and classification of financial items, etc. The financial management aspects of privatization are highly linked to the countries' developments in accounting and auditing in nature, Accountancy firms have been the one of the dominant providers of privatization advisory services. There are some factors such as economic, political, and 
the significance to professionalism's cultural capital which explain why professional technicians and particularly private sector accounting firms came to play such a prominent role in the privatization industry, and Playing a critical role in privatization process, and the role of accounting and financial reporting in privatization can be analyzed under five subsections that are disclosure, transitional problems, training, valuation problems, and inflation accounting (Craig, R., \& Amernic, J., 2006).

Therefore, valuation of the privatized companies (and their assets and or shares) is one of the most difficult problems of privatization. Valuation problems related to the privatization of SOEs can be analyzed in three groups:

a) The valuation of assets and liabilities;

b) The valuation of business as a going concern; and

c) The determination of the final sales price for assets and/or shares of the company.

The issues related to these groups of valuation problems are interrelated, but are seldom, if ever, identical. The valuation of the enterprises to be privatized is important for the Government to maintain its credibility in the privatization process. Also, it is important to achieve the appropriate sales price (Selvi \& Yilmaz, 2009).

In terms of the standard budgetary accounting conventions, the case for privatization of government business enterprises appears unanswerable. The whole of the sale price of the asset concerned is recorded as an offset against outlays (or, in some jurisdictions as revenue). This analysis reflects the generally defective nature of the budget deficit as a measure of public saving. The budget deficit is simply a measure of cash flow and is confined to the 'budget sector, the fact that the budget is a cash flow measure means that capital and current expenditures are lumped together. Similarly asset sales from within the budget sector are treated as current income (or, in some budget systems, as an offset against current expenditure). Thus, the budget deficit is useful as a measure of public saving only if the level of net public investment (new investment less asset sales) is essentially constant (John Quiggin, 1997).

The following sections will focus on the viewpoints of those who are critical towards the current theories on privatization. Although the privatization process is vital to improve the economy and stimulate firm performance in LDCs, the Western approach is not always the most suitable one. There are a large number of specific factors that influence the outcome of the privatization process in developing countries. These will be dealt with in section 2.5. It is argued that in the case of LDCs, privatization issue should be approached from a broader perspective. Moreover, the current theories do not fully explain how organizational change processes actually take place. Below a summary is given of the main points of criticism with respect to the various theories.

Production Efficiency Theories: Principal-Agent relationships may be common in small firms, but in the large modern limited liability corporation the property rights are diluted. Diluted ownership reduces the control of owners over managers. As a result, managers have a considerable amount of freedom to back their own interests. Moreover, the implications of ownership with respect to production and efficiency depend to a high degree on the nature of the business environment. These environmental factors have a considerably larger impact on firm performance than ownership. Therefore, apart from ownership, these factors, including competition and regulation, have to be taken into account when assessing the privatization process

Agency Theory: Critics argue that the empirical validity of the views on which this theory is based is dubious. Full information is hard to obtain in practice and thus information processing is highly complex. Moreover, internal conflicts undermine communication between organizational members. In addition, in LDCs the competitive markets are still poorly organized, and the economic relationships and motivations are much more complex than is being portrayed by the agency theory. It is difficult to model them by means of this theory. For example, trust is not dealt with. Further, the relation between a manager's efforts and the output in terms of profitability is more difficult to determine than is being suggested in this theory.

Allocate Efficiency: Critics argue that allocate efficiency also applies to public enterprises. Deregulation, liberalization and competition are important conditions for the success of privatization programmers, but not essential (Jackson \& Palmer, 1988). In addition, the fiscal effects of privatization are overrated, especially the reduction in budget deficits through the elimination of financial subsidies (Adam et al., 1992). Subsidies are the result of budget policies and they may continue after privatization, for example, price support for farmers.

Property Rights: Property rights that are poorly defined, insufficient protection against theft and expropriation, breach of contract, these are all factors that undermine efficiency.

Control over the evaluation of the assets and liabilities of the project References should at this stage, check the 
following:

- Ensure that the authority concerned to prepare a comprehensive evaluation of the project before Privatized.

- Ensure that the assessment is comprehensive and independence and impartiality.

- Ensure that persons who evaluation do not have any interest directly or indirectly, in the privatization process, where there is a risk is that those responsible for the privatization processes may want to Achieve their personal profit public interest expense. It can this danger that takes many forms and prosper in the midst of uncertainty and uncertainty surrounding such business processes. (Control over the work of the privatization of Supreme Audit Institutions of the Gulf Cooperation Council (GCC) guide Arab Gulf, 2013).

\section{Method}

\subsection{Sample Size, Power, and Precision}

The numbers of companies that have been privatized are eight companies according to the study sample so that the distribution of 380 questionnaires was to recover 274 questionnaires and found them valid for the purposes of statistical analysis to identify 251 of the restitution and $80 \%$ recovery rate.

\subsection{Measures and Covariates}

Research plan consisted of two main parts:

1-Theoretical side

Study of major ideas in different theoretical aspects where the researcher addressed the definition of privatization, stages and steps, and the pros and cons of privatization process and accounting procedures used in the privatization process and accounting methods to evaluate the assets of the enterprises are privatized.

\section{2- Practical side}

The study population and sample and measurement standards, and tests of honesty and reliability measurement tool and methods of data collection and statistical methods used to analyze the data and results. The study is exploratory or descriptive type survey based on opinions or attitudes of the study sample, where this study was conducted on a sample of internal auditors in companies privatized service in Jordan.

\section{Results}

\subsection{Reliability and Validity}

Been using Alpha Cronbach test to find the degree of internal consistency between the answers sample and found the value of Alpha by statistical analysis of the questionnaires distributed program and found that the alpha value is the premise of the first $79 \%$ and the hypothesis of the second $82 \%$ and the value of the alpha of the study are $81 \%$ higher than the minimum value accepted statistically It $60 \%$.

\subsection{Description of Study Sample}

Table 1. Study sample according to specialization

\begin{tabular}{lcc}
\hline Statement & Frequent & Percentage \\
\hline Administrative Sciences & 38 & $16 \%$ \\
Financial Sciences & 51 & $22 \%$ \\
Accounting & 146 & $62 \%$ \\
Total & 235 & $100 \%$ \\
\hline
\end{tabular}

Notes from Table 1 that the vast majority of the members of the study sample are allocated accounting, and this means the presence of a trend in companies that have been privatized to appoint specialists in accounting and this is a positive point in the study sample and the index of the sincerity and understanding of the paragraphs of the questionnaire and this gives credibility and stability for statements of questionnaire 
Table 2. Study sample by years of experience

\begin{tabular}{lcc}
\hline Statement & Frequent & Percentage \\
\hline 1-less 6 years & 54 & $23 \%$ \\
6-12 years & 104 & $44 \%$ \\
12 years and more & 77 & $33 \%$ \\
Total & 235 & $100 \%$ \\
\hline
\end{tabular}

Notes from Table 2 that the majority of the study sample individuals from their experience in the 6-12 category a year and this is a positive indicator, so we can say that the paragraphs of the questionnaire was supported by specialization of scientific and appropriate experience and this may give a degree of stability to the findings and recommendations of the study, and that the notes from the experience of more than 12 year them second-class members of the study sample characteristics and the power point to search

\subsection{Base Decision}

Been using the questionnaire as a tool for the study was distributed to accountants in companies that were privatized in Jordan so that was distributed 310 questionnaires were collected 251 questionnaire so the recovery ratio of $81 \%$, contained the resolution clauses covering the variables of the study so that was given five options for each paragraph: strongly $\mathrm{OK}, \mathrm{OK}$, neutral, not $\mathrm{OK}$ and not $\mathrm{OK}$ strongly was given the following codes when using statistical analysis program: strongly OK 5, indicated by the symbol OK 4 , and 3 neutral symbol, and the symbol 2 is not OK and not OK strongly indicated by 1 . Therefore, the central premise is to be number 3 $(1+2+3+4+5) / 5$, so if the average paragraph in the resolution 3 or more, it means that the study sample confirm the existence of that paragraph and the greater the average for the number 3 whenever increased degree of confirmation, and the lower the average for the number 3 , it means that the sample of the study do not support that paragraph in the study sample corporate members.

\subsection{Discuss the Statistical Results by the Arithmetic Mean and Standard Deviation with the Hypotheses of the} Study

First hypothesis: There is no trace of the objectives of privatization accounting on the financial statement.

Table 3. Opinions of the study sample application of accounting goals in privatization

\begin{tabular}{|c|c|c|c|c|}
\hline Number & Statement & Average & Standard deviation & Rank \\
\hline 1 & $\begin{array}{l}\text { Making divestitures decision such as the type of privatization method to use and its } \\
\text { timing }\end{array}$ & 2.48 & 0.455 & 8 \\
\hline 2 & $\begin{array}{l}\text { Fulfilling the investors' needs, which usually include as a minimum the preparation } \\
\text { of prospectus or information memorandum and business plan }\end{array}$ & 4.16 & 0.528 & 3 \\
\hline 3 & $\begin{array}{l}\text { Assessing how the public interest has been served in the government discharged of its } \\
\text { stewardship function, 4including how will the privatization objectives has been met }\end{array}$ & 3.27 & 0.731 & 5 \\
\hline 4 & Increase disclosure in financial statement after privatization & 4.75 & 1.16 & 1 \\
\hline 5 & $\begin{array}{l}\text { Making value added for financial statement after privatization by provide internal } \\
\text { auditing and external auditing }\end{array}$ & 2.63 & 0.472 & 7 \\
\hline 6 & $\begin{array}{l}\text { Identification of property unsuitable for business activity as uncollectible claims, } \\
\text { fixed and intangible assets, and investments items }\end{array}$ & 3.09 & 0.857 & 6 \\
\hline 7 & $\begin{array}{l}\text { Accounting language is important in telling the tale of privatization. Of particular } \\
\text { importance are the specific constructs in that language }\end{array}$ & 3.59 & 0.927 & 4 \\
\hline 8 & $\begin{array}{l}\text { The accounting measures used to help construct the tale, give it a coursing thread } \\
\text { through time, and generate rhetorical appeal }\end{array}$ & 4.29 & 0.643 & 2 \\
\hline Average & & 3.53 & & \\
\hline
\end{tabular}

Notes from Table 3 that the study sample that Jordanian companies after privatization process is applied increase in the disclosure of accounting operations through paragraph 4 and its average 4.75 This means that the 
accounting disclosure processes become more than after the privatization process may be the reason there are new shareholders need to data and additional information about the numbers in the financial statements, $\mathrm{He}$ also notes that the eighth paragraph represents the second degree of acceptance and an average of 4.29 represented by this paragraph the accounting measures used to help construct the tale, give it a coursing thread through time, and generate rhetorical appeal, notes that the second paragraph represents Continuing get prospectuses related companies after the privatization process in which there is all the information relating to the company and help stakeholders in making investment decisions in a timely manner, and this increases the reliability and credibility of the financial statements and the statements contained therein and the future of the company and the achievement of its goals, also notes the first paragraph represents the lowest acceptance of the study sample That which is less than the middle premise 3 and an average of 2.48 that must companies privatization of where there is no diversity in the investment may be ordered Legacy of previous administrations where the financial statements there is no diversity in the corporate investments must privatization which may lead to a decline in the level of investment, both existing investors or prospective investors. That which is greater than the mean premise 3 also notes the average 3.53 hypothesis and this shows that the study sample supports the alternative hypothesis rejects the hypothesis nihilism, and this shows that the companies after privatization benefited from the accounting objectives of the privatization process.

Second hypothesis: Do not use the companies after privatization accounting measurement methods in the preparation of financial statements.

Table 4. Sample the opinions of the application of the accounting measurement methods for companies after privatization

\begin{tabular}{|c|c|c|c|c|}
\hline Number & Statement & Average & Standard deviation & Rank \\
\hline 1 & $\begin{array}{l}\text { Evaluate the assets of institutions, is to try to reach a financial value, but this } \\
\text { value is indicative estimated }\end{array}$ & 3.46 & 0.482 & 5 \\
\hline 2 & $\begin{array}{l}\text { Problems change in accounting systems: a change in accounting methods } \\
\text { resulting from the transfer of ownership of accounting units }\end{array}$ & 4.09 & 0.761 & 2 \\
\hline 3 & $\begin{array}{l}\text { Changes in accounting and financial systems, and the quality of the available } \\
\text { financial information, required after privatization }\end{array}$ & 2.51 & 0.573 & 8 \\
\hline 4 & $\begin{array}{l}\text { The information that explains the economic situation, and the project's } \\
\text { financial feasibility and economic problems disclosed in financial statements }\end{array}$ & 3.82 & 0.768 & 3 \\
\hline 5 & $\begin{array}{l}\text { Assets are evaluating depending on the estimated price of the sale between the } \\
\text { seller and the buyer without pressure Or coercion }\end{array}$ & 4.39 & 0.886 & 1 \\
\hline 6 & $\begin{array}{l}\text { Method based on the replacement cost: represents the present value of the } \\
\text { replacement owned enterprise assets }\end{array}$ & 3.79 & 0.914 & 4 \\
\hline 7 & $\begin{array}{l}\text { The value is estimated based on the expected price of the shares in an efficient } \\
\text { and active market for Using a multiplier market value consideration for the } \\
\text { shares for profit }\end{array}$ & 2.38 & 1.08 & 9 \\
\hline 8 & $\begin{array}{l}\text { The growth of accounting within these public sector organizations can be seen } \\
\text { as a response to this growing commercial and competitive environment }\end{array}$ & 3.07 & 0.655 & 6 \\
\hline 9 & $\begin{array}{l}\text { Government accounting is a key component of accountability and transparency } \\
\text { by keeping the records of and reports the financial policy related government } \\
\text { transactions }\end{array}$ & 2.76 & 0.537 & 7 \\
\hline Average & & & 3.36 & \\
\hline
\end{tabular}

Notes from Table 4 that the study sample supports primarily paragraph No. 5, which relate to that property transfers from the public sector to the private sector are implemented according to the agreement between the seller and the buyer a negotiated price without making any modifications to the agreement, and that means taking the values of the habit of items lists Finance whether the seller or the buyer and this is a good indicator of the adoption of the fair values of the items of financial statements, also notes that the second paragraph represents the degree of the second acceptance by Ray sample study that confirms the existence of accounting problems when ownership of projects move from the public sector to the private sector personnel and that means 
must provide a clear accounting policies for the transition from the public sector to the private sector and know how to disclose the impact of changes in the accounting policies of the companies after privatization and how to recognize gain or loss as a result of the change in accounting policies and how disclosed in the financial statements, also notes that the fourth paragraph represents the degree of the third acceptance of the members of the study sample which relates to the necessity of interpretation of financial statements and their relationship to economic conditions and must be disclosed in the financial statements after the privatization process due to the presence of new shareholders in the companies after privatization, and this helps to create additional value for the credibility of financial statements, also notes that the seventh paragraph represents the lowest acceptance by study sample which represents

The value is estimated based on the expected price of the shares in an efficient and active market for using a multiplier market value consideration for the shares for profit. He also notes that the average hypothesis is 6.36, higher than the central premise, and this shows that the study sample agree to the alternative hypothesis rejects the hypothesis nihilism, so the members of the study sample in favor of the companies that have been privatized used accounting methods related to privatization.

\section{Conclusions and Recommendation}

\subsection{Conclusions}

1) The Jordanian firms after privatization disclose all financial statements in the financial statements process applied and this means that it applies the principles of financial accounting accepted.

2) Fulfilling the investors' needs, which usually include as a minimum the preparation of prospectus or information memorandum and business plan.

3) The Jordanian companies before privatization process depends on the measurement accounting methods work as a reciprocal process of accounting disclosure in the financial statements.

4) Assessing how the public interest has been served in the government discharged of its stewardship function, including how will the privatization objectives has been met.

5) Determine the value of assets and liabilities of companies after privatization depends on direct negotiations between the seller and the buyer according situation and current prices in the market and this gives greater credibility to the financial statements after privatization.

6) There are problems in the change of accounting policy for companies after privatization, and this leads to the existence of unrealized gains or unrealized losses and generates problems in recognition of those losses or profits in the financial statements, and that means the need to provide a private accounting policies of the companies after the privatization process to overcome these problems.

7) The information that explains the economic situation, and the project's financial feasibility and economic problems disclosed in financial statements.

8) Method based on the replacement cost represents the present value of the replacement owned enterprise assets.

\subsection{Recommendations}

1) It's important to care that the value is estimated based on the expected price of the shares in an efficient and active market for using a multiplier market value consideration for the shares for profit.

2) Changes in accounting and financial systems, and the quality of the available financial information, required after privatization.

3) Government accounting is a key component of accountability and transparency by keeping the records of and reports the financial policy related government transactions.

4) The growth of accounting within these public sector organizations can be seen as a response to this growing commercial and competitive environment.

5) Making divestitures decision such as the type of privatization method to use and its timing.

6) Making value added for financial statement after privatization by provide internal auditing and external auditing.

7) Identification of property unsuitable for business activity as uncollectible claims, fixed and intangible assets, and investments items. 


\section{References}

Andrea, M. (2013). Accounting and privatization in the prison service of england and wales. Financial Accountability \& Management, 29(2), 0267-4424.

Coelye. (2007). Policy and operational implications of prison privatization. Paper presented at the Scottish Consortium on Crime and Criminal Justice Colloquium (City).

Craig, R., \& Amernic, J. (2006). The mobilization of accounting in preening for privatization. Accounting, Auditing \& Accountability Journal, 19(1), 82-95. http://dx.doi.org/10.1108/09513570610651957

Gupta, A. (2000). Beyond privatization. Vhps Distribution.

Kerry, J. (2009). Beyond commercial in confidence: Accounting for power privatization in Victoria. Accounting, Auditing \& Accountability Journal, 22(8), 1258-1283. http://dx.doi.org/10.1108/09513570910999300

Mohmoud, A. (2012). Fixed asset valuation for the purposes of privatization: The case of Aqaba Railway Corporation in Jordan. Albaheth Journal, 249.

Ogden, S. G., \& Anderson, F. (1999). The role of accounting in organizational change: Promoting performance improvements in the privatized UK water industry. Critical Perspectives on Accounting, 10, 91-124. http://dx.doi.org/10.1006/cpac.1998.0200

Quiggin, J. (1997). Privatization: What to count? Australian Accountant, 18-9 April.

Selvi, Y., \& Yilmaz, F. (2009). The relationship between accounting and privatization. Istanbul University, Institute of Accounting, Istanbul.

Shehab, H. S. (2008). Problematic privatization and its implications in raising the efficiency of economic performance. Alanbar Journal for Managerial Studies, Iraq.

Uddin, S., \& Hopper, T. (2003). Accounting for privatization in Bangladesh: Testing World Bank claims. Critical Perspectives on Accounting, 14, 739-774. http://dx.doi.org/10.1016/S1045-2354(02)00188-0

Yakup, S. (2010). The importance of financial reporting during privatization: Turkish case. Annales Universitatis Apulensis Series Oeconomica, 12(2).

Young, P. (1998). The lessons of privatization. Economic Reform Today, (1), 2-7.

\section{Copyrights}

Copyright for this article is retained by the author(s), with first publication rights granted to the journal.

This is an open-access article distributed under the terms and conditions of the Creative Commons Attribution license (http://creativecommons.org/licenses/by/3.0/). 